\title{
VALIDITAS MODUL PRAKTIKUM BERORIENTASI KETERAMPILAN PROSES SAINS DAN PENDIDIKAN KARAKTER
}

\author{
Arie Arma Arsyad ${ }^{\text {a) }}$, Dewi Sartika ${ }^{\text {b) }}$ \\ Program Studi Pendidikan Fisika, FKIP, Universitas Sulawesi Barat \\ Email: a) ariearmaarsyad@unsulbar.ac.id , b) dewi.sartika@unsulbar.ac.id
}

\begin{abstract}
Abstrak
Penelitian ini bertujuan untuk mengembangkan modul praktikum fisika dasar berorientasi keterampilan proses sains dan pendidikan karakter yang memenuhi kriteria valid. Penelitian ini merupakan penelitian pengembangan sesuai dengan model 4-D oleh Thiagarajan yang meliputi: (1) Tahap Pendefinisian (Define), (2) Tahap Perancangan (Design), (3) Tahap Pengembangan (Develop), dan (4) Tahap Penyebaran (Disseminate). Hasil Penelitian menunjukkan bahwa modul praktikum fisika dasar ini layak untuk digunakan dalam proses pembelajaran pada kategori penilaian sangat baik.
\end{abstract}

Kata-kata kunci: modul praktikum fisika dasar, keterampilan proses sains, pendidikan karakter.

\begin{abstract}
This research aimed to develop a basic physics lab module oriented science process skills and character education are valid criteria. This research was a development research used the 4-D model by Thiagarajan which includes: (1) Defining Phase, (2) Design Phase, (3) Development Phase, and (4) Disseminate Phase. The results of the study showed that this basic physics practicum module was valid to use in learning with very good category.
\end{abstract}

Keywords: basic physics lab module, science process skills, character education.

\section{PENDAHULUAN}

Kurikulum pendidikan baik di tingkat perguruan tinggi maupun sekolah menitikberatkan pada student active learning. Pada pembelajaran sains memberikan kesesmpatan kepada peserta didik utuk beraktivitas, baik itu hands on activities maupun minds on activities. Rinsiyah (dalam Sumintono 2010)[1] menjelaskan bahwa terdapat paling sedikit tiga fokus utama dalam pembelajaran sains di sekolah yaitu berbentuk: (1) produk dari sains, berupa pengetahuan ilmiah yang penting diketahui oleh siswa (hard skills); (2) sains sebagai proses yang berkonsentrasi sebagai metode pemecahan masalah untuk mengembangkan keahlian siswa untuk memecahkan masalah (hard skills dan soft skills); dan (3) sains sebagai pendekatan sikap dan nilai ilmiah (soft skills).

Fisika sebagai bagian dari ilmu sains merupakan wahana pendidikan yang tidak hanya digunakan untk mencapai tujuan misalnya mencerdaskan peserta didik, akan tetapi dapat pula membentuk karakter siswa serta mengembangkan keterampilan tertentu. Lebih lanjut lagi, Semiawan dalam Misbah (2018) [2], keterampilan proses sains sangat penting untuk dimiliki oleh mahasiswa karena mahasiswa dapat dengan mudah memahami materi yang bersifat abstrak melalui pembelajaran yang nyata dan dapat mengembangakn konsep yang sifatya tidak lepas dari sikap dan nilai. Keterampilan 
proses sains dapat dilatihkan melalui kegiatan praktikum atau eksperimen dengan menggunakan bahan ajar yang tepat. Hal ini disebabkan dengan menggunakan bahan ajar yang tepat, mahasiswa dapat menyelesaikan suatu masalah dengan menggunakan penyelidikan yang dapat melatihkan keterampilan proses sains dan mengembangkan karakter mahasiswa seperti tanggung jawab dan kerja sama

Hal itu mengarahkan perhatian kepada pembelajaran nilai-nilai kehidupan melalui fisika. Pelaksanaan pembelajaran yang berorientasikan keterampilan proses sains dan pendidikan karakter di Prodi Pendidikan Fisika sudah dirancang sejak lama. Sayangnya, pelaksanaan belum optimal sehingga situasi dan kondisi dalam mengembangkan keterampilan proses sains dan pendidikan karakter belum kondusif. Salah satunya hambatan yang dialami adalah dosen belum mempunyai bahan ajar yang tepat pada perkuliahan yang berupa modul praktikum dan asesmen penilaian.

Hal senada dikemukakan pula Koesoema (2017) [3] menyatakan bahwa salah satu kunci keberhasilan dalam mengembangkan keterampilan proses sains dan pendidikan karakter terletak pada peranan dosen. Pelatihan dan penanaman nilai-nilai karakter dimulai dari internalisasi bahan ajar yang berorientasikan keterampilan proses sains dan pendidikan karakter dengan baik. Berkaitan dengan hal itu, dosen dituntut untuk merancang dan menyusun bahan ajar yang dapat mengakomodir pembelajaran untuk mengembangkan keterampilan proses sains dan pendidikan karakter. Dalam menerapkan keterampilan proses sains dan pendidikan karakter, perlu disusun bahan ajar yang sesuai. Tujuan utama dari pelaksanaan penelitian ini adalah terwujudnya bahan ajar dan implementasi yang baik dalam mengembangkan keterampilan proses sains dan pendidikan karakter

\section{METODOLOGI}

Model pengembangan modul praktikum pada penelitian ini menggunakan model 4-D yang diadaptasi menjadi model 4-P (Ibrahim, 2005) [4] yang terdiri dari 4 tahap yaitu tahap pendefinisian (define), perancangan (design), pengembangan (develop), dan penyebaran (disseminate). Dari 4 tahap ini, digunakan tiga tahapan sampai pada tahap pengembangan.

\section{Define}

Pada tahap ini, peneliti menganalisis kebutuhan terutama pada kurikulum yang digunakan, menganalisis karakteristik peserta didik, menganalisis materi, konsep, dan merumuskan tujuan pembelajaran.

\section{Design}

Setelah dilakukan tahap pendefinisian, langkah selanjutnya adalah menyusun unit-unit praktikum, memilih format modul praktikum, dan merancang dan membuat modul praktikum fisika dasar berorientasi keterampilan proses sains dan pendidikan karakter.

\section{Development}

Proses validasi dilakukan oleh tiga validator. Instrumen yang digunakan pada tahap validasi menggunakan skala Likert dengan skor 1 = sangat tidak layak, 2 = tidak layak, 3 = layak, dan $4=$ sangat layak. Hasil penilaian validitas kemudian dihitung dengan cara:

$$
\text { persentase skor }=\frac{\sum \text { skor yang diperoleh }}{\sum \text { skor maksimum }} \times 100 \%
$$

Persentase skor yang diperoleh kemudian diukur menggunakan interpretasi skor untuk skala Likert: 
TABEL 1. Pedoman Kriteria Kelayakan

\begin{tabular}{cc}
\hline Persentase (\%) & Interpretasi \\
\hline $0-25$ & Sangat Tidak Layak \\
\hline $26-50$ & Tidak Layak \\
\hline $51-75$ & Layak \\
\hline $76-100$ & Sangat Layak \\
\hline Sumber: Ardiyanti, dkk (2018) [5]
\end{tabular}

\section{HASIL DAN PEMBAHASAN}

\section{HASIL DAN PEMBAHASAN}

Produk yang dikembangkan pada penelitian ini berupa modul praktikum fisika dasar dalam bentuk cetak. Dalam proses pengembangannya, modul ini juga membandingkan dengan modul praktikum yang telah dikembangkan sebelumnya [6-7], konten keterampilan proses sains [8-10], dan pendidikan karakter [11]. Modul praktikum ini terdiri dari beberapa komponen, yaitu cover, kata pengantar, daftar isi, petunjuk penggunaan, peta konsep, tujuan pembelajaran, materi singkat, tahapan keterampilan proses sains, dan daftar pustaka. Modul praktikum ini setiap tahapan keterampilan proses sains dilengkapi dengan pendidikan karakter yang dikembangkan.

\section{Validasi}

Jika Anda menampilkan banyak gambar, Anda dapat menggunakan TABEL agar pengaturannya lebih mudah. Antara gambar dan paragraf di atasnya sisakan satu spasi seperti ini.

TABEL 2. Indikator Penilaian

\begin{tabular}{llc}
\hline No. & \multicolumn{1}{c}{ Indikator } & $\begin{array}{c}\text { Hasil Uji } \\
\text { Validitas (\%) }\end{array}$ \\
\hline & Desain Modul & \\
\hline 1 & Desain cover & 91,7 \\
\hline 2 & Kata Pengantar & 91,7 \\
\hline 3 & Daftar Isi & 83,3 \\
\hline 4 & Standar Isi & 83,3 \\
\hline 5 & Peta Konsep & 83,3 \\
\hline 6 & Glosarium & 83,3 \\
\hline 7 & Uraian Isi Materi & 91,7 \\
\hline 8 & Desain Gambar dan Pewarnaan & 83,3 \\
\hline 9 & Daftar Pustaka & 83,3 \\
\hline & Organisasi dan Kebahasaan & 83,3 \\
\hline 1 & Penyusunan antar unit praktikum menunjukkan keruntutan & 83,3 \\
\hline 2 & Bahasa yang digunakan jelas dan sesuai konsep & 91,7 \\
\hline 3 & Menggunakan bahasa yang sesuai pedoman EYD & 91,7 \\
\hline 4 & Tidak terdapat kalimat yang bermakna ambigu & 83,3 \\
\hline 5 & Bahasa yang digunakan sesuai dengan perkembangan kognitif peserta didik & \\
\hline & Materi & 83,3 \\
\hline 1 & Kesesuaian materi dengan kompetensi dasar &
\end{tabular}




\begin{tabular}{rlc}
\hline 2 & Kesesuaian materi dengan tujuan pembelajaran & 91,7 \\
\hline 3 & Kebenaran konten (fakta, konsep, prinsip, hukum, teori, dan proses ilmiah) & 100,0 \\
\hline 4 & Peta konsep sesuai dengan materi dan mudah dipahami & 83,3 \\
\hline & $\begin{array}{l}\text { Terdapat kegiatan praktikum yang membantu peserta didik memahami konsep } \\
\text { fisika secara tepat }\end{array}$ & 100,0 \\
\hline & $\begin{array}{l}\text { Penyusunan modul mendukung peserta didik untuk mengembangkan } \\
\text { keterampilan proses sains }\end{array}$ & 83,3 \\
\hline & Format & 91,7 \\
\hline 1 & Materi setiap kegiatan relevan dengan tujuan & 83,3 \\
\hline 2 & Teks dan ilustrasi berimbang & 100,0 \\
\hline & Konsisten dalam penggunaan jarak spasi, jarak antara judul dengan baris \\
\hline 3 & pertama, dan antara judul dengan teks utama & 91,7 \\
\hline 4 & Konsisten penggunaan istilah atau simbol & 91,7 \\
\hline 5 & Bentuk dan ukuran huruf mudah dibaca & 91,7 \\
\hline & Penyajian & 91,7 \\
\hline 1 & Membangkitkan motivasi/minat/rasa ingin tahu & 91,7 \\
\hline 2 & Sesuai dengan taraf berpikir dan kemampuan membaca & 91,7 \\
\hline 3 & Mendorong peserta didik terlibat aktif & 83,3 \\
\hline 4 & Menarik/menyenangkan & 91,7 \\
\hline & Peningkatan Mutu KBM & \\
\hline 1 & Kesesuaian dengan kurikulum pendidikan & Menunjang terlaksananya proses belajar mengajar yang lebih diwarnai oleh \\
\hline 2 & student active learning
\end{tabular}

Rata-rata hasil penilaian modul praktikum fisika dasar dapat dinaytakan dalam bentuk grafik sebagai berikut:

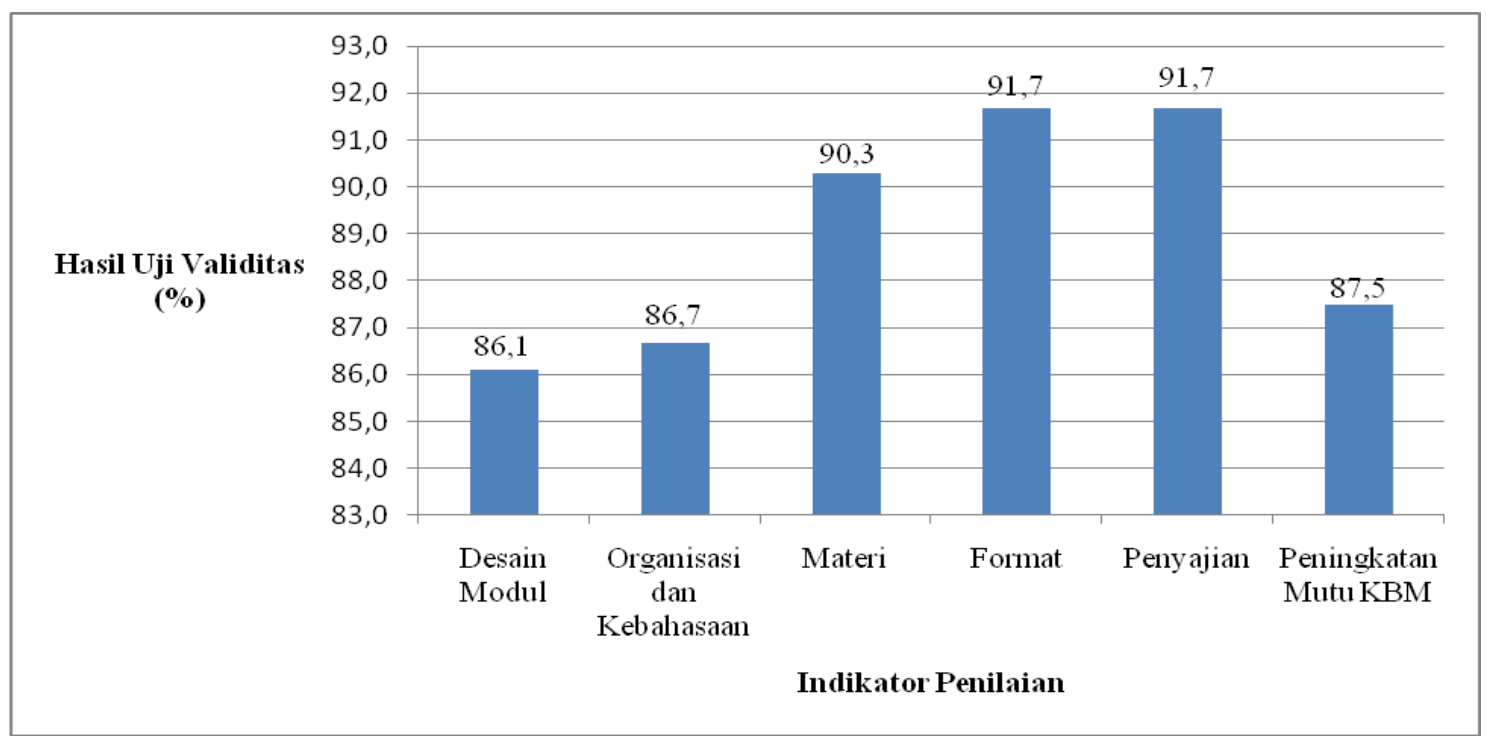

GAMBAR 1. Grafik hasil uji kelayakan oleh validator

Hal yang dinilai oleh validator mencakup desain modul, organisasi dan kebahasaan, materi, format, penyajian, dan peningkatan mutu kegiatan belajar mengajar. Berdasarkan hasil pada TABEL 
2 dan Grafik 1 menunjukkan bahwa modul ajar fisika dasar berorientasi keterampilan proses sains dan pendidikan karakter sangat layak digunakan dalam proses pembelajaran fisika dasar.

\section{SIMPULAN}

Berdasarkan hasil penelitian dan uji kelayakan dapat disimpulkan bahwa modul praktikum fisika dasar yang dikembangkan termasuk dalam kategori sangat layak digunakan dalam proses pembelajaran mata kuliah fisika dasar.

\section{REFERENSI}

[1] Rinsiyah, Iis. (2016). Pengembangan Modul Fisika Berbasis CTL untuk Meningkatkan KPS dan Sikap Ilmiah Siswa Madrasah Aliyah. Jurnal Pendidikan Matematika dan Sains Volume 4 Nomor 2 pp. $152-162$.

[2] Misbah, dkk. (2018). Pengembangan Petunjuk Praktikum Fisika Dasar 1 Berbasis 5M untuk Melatih Keterampilan Proses Sains dan Karakter Wasaka. Jurnal Fisika FLUX Volume 15 Nomor 1 Februari 2018 ISSN: 1829-796X.

[3] Koesoema, Doni A. (2017). Pendidikan Karakter Berbasis Kultur Sekolah. Yogyakarta: PT Kanisius.

[4] Ibrahim. (2005). Asesmen Berkelanjutan. Surabaya: Unipress Unesa.

[5] Ardiyanti, dkk. (2018) Pengembangan Ensiklopedia Alat Optik Berbasis Problem Based Learning. Seminar Nasional Fisika Volume VII Oktober 2018 pp 9 - 15.

[6] U. Usmeldi, "Pengembangan Modul Pembelajaran Fisika Berbasis Riset dengan Pendekatan Scientific untuk Meningkatkan Literasi Sains Peserta Didik", jpppf, vol. 2, no. 1, pp. 1 - 8, Jun. 2016.

[7] M. L. Dewi, A. S. Budi, and E. Budi, "PENGEMBANGAN MODUL PRAKTIKUM FISIKA BERBASIS DATA LOGGER UNTUK SMA", PROSIDING SNF, vol. 4, pp. SNF2015-II, Oct. 2015.

[8] M. Yusuf and A. R. Wulan, "Penerapan Model Pembelajaran Discovery Learning Menggunakan Pembelajaran Tipe Shared dan Webbed untuk Meningkatkan Keterampilan Proses Sains”, jpppf, vol. 1, no. 2, pp. 19 - 26, Dec. 2015.

[9] A. Malik, "Model Pembelajaran Problem Based Instruction untuk Meningkatkan Penguasaan Konsep dan Keterampilan Proses Sains Mahasiswa", jpppf, vol. 1, no. 1, pp. 9 - 16, Jun. 2015.

[10] A. Malik, E. Kurnia Y, and S. Robiatus S, "Peningkatan Keterampilan Proses Sains Siswa melalui Context Based Learning", jpppf, vol. 2, no. 1, pp. 23 - 30, Jun. 2016.

[11] Tirmayasari, T., Jufri, A. W., \& Harjono, A. (2019). Validitas Perangkat Pembelajaran IPA Berbasis Masalah Bermuatan Karakter. Jurnal Pendidikan Fisika dan Teknologi, 5(2), 221 226. 
